\title{
Prevalence of Helicobacter spp in chronic cholecystitis and correlation with changes on the histological pattern of the gallbladder ${ }^{1}$
}

\author{
Prevalência do Helicobacter spp na colecistite crônica calculosa e correlação com as alterações \\ histológicas da vesícula biliar
}

\author{
André de Moricz ${ }^{\mathrm{I}}$, Murilo Melo ${ }^{\mathrm{II}}$, Ana Maria Castro ${ }^{\mathrm{III}}$, Tercio de Campos ${ }^{\mathrm{IV}}$, Rodrigo Altenfelder Silva ${ }^{\mathrm{V}}$, Adhemar Monteiro \\ Pacheco JrV \\ ${ }^{I} \mathrm{PhD}$, Instructor Professor, Department of Surgery, Faculty of Medical Sciences, Santa Casa School of Medicine, São Paulo, Brazil. \\ ${ }^{\text {II }} \mathrm{PhD}$, Assistant Professor, Department of Physiological Sciences, Laboratory of Molecular Medicine, Faculty of Medical Sciences, Santa Casa School \\ of Medicine, São Paulo, Brazil.

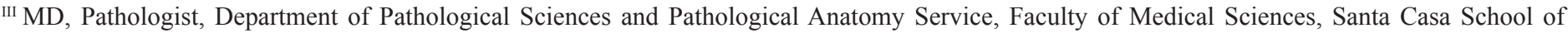 \\ Medicine, São Paulo, Brazil. \\ ${ }^{\text {IV }} \mathrm{PhD}$, Assistant Professor, Department of Surgery, Faculty of Medical Sciences, Santa Casa School of Medicine, São Paulo, Brazil. \\ ${ }^{v} \mathrm{PhD}$, Associate Professor, Department of Surgery, Faculty of Medical Sciences, Santa Casa School of Medicine, São Paulo, Brazil.
}

\begin{abstract}
Purpose: Establish the prevalence of Helicobacter spp in chronic cholecystitis and its correlation with the gallbladder's histological findings. Methods: 100 patients were operated for chronic cholecystitis with cholecystolithiasis. In pathological examination of the gallbladder, were evaluated the presence of metaplasia, dysplasia, lymphoid follicles, anaplasia and tumors that might be related to the presence of Helicobacter plus the presence of the bacilli Giemsa $\oplus$ by optical microscopy. From the DNA extracted from the gallbladder's bile, PCR was performed by using specific primers for the identification of Helicobacter spp with amplification of the 400bp segment of rRNA gene16S, with positive control DNA from Helicobacter pylori. All the cases negative for isolation of genetic material were excluded. The cases of PCR $\Theta$ and Giemsa $\Theta$ were used as negative control group. The histological findings were compared to the presence of bacilli and PCR data using a chi-square and Fisher's Exact test $(\mathrm{CI}=95.0 \%, \mathrm{p}<0.05)$. Results: Of 68 patients, 42 (61.8\%) were PCR $\oplus$ for Helicobacter spp and 19 (27.9\%) had Giemsa $\oplus$. There was no correlation between the two findings. The PCR $\oplus$ for Helicobacter spp was not correlated to the histological findings. The presence of lymphoid follicles and metaplasia was related to the Giemsa $\oplus(p=0.025$ and $p=0.039)$. Conclusion: There is high prevalence of Helicobacter spp in patients with chronic cholecystitis and cholecystolithiasis without be correlated with the histological patterns studied.
\end{abstract}

Key words: Helicobacter. Polymerase Chain Reaction. Bile. Cholecystitis.

\section{RESUMO}

Objetivo: Estabelecer a prevalência do Helicobacter spp nos doentes com colecistopatia crônica calculosa e correlacioná-la com as alterações histológicas da vesícula biliar. Métodos: Foram operados 100 doentes portadores de colecistite crônica calculosa. No anátomo-patológico foram avaliadas a presença de, metaplasias, displasias, folículos linfóides, anaplasias e tumores que pudessem se relacionar à presença do helicobacter e a presença de bacilos Giemsa $\oplus$ à microscopia. A partir do DNA extraído da bile foi realizada PCR utilizando-se primers específicos para identificação de Helicobacter spp com amplificação de segmento de 400bp do gene16S rRNA, com controle positivo de DNA de Helicobacter Pylori. Os casos negativos para isolamento de material genético na bile foram excluídos. Os casos de PCR e Giemsa negativos foram utilizados como grupo controle. Os achados histológicos foram comparados ao Giemsa e à PCR utilizando-se Teste do Qui-Quadrado e Exato de Fisher (IC=95,0\%; p <0,05). Resultados: De 68 doentes, 42(61,8\%) apresentaram PCR $\oplus$ para Helicobacter spp e 19(27,9\%) Giemsa $\oplus$. Não houve correlação entre os dois achados. Não houve correlação entre alterações histológicas e a PCR $(\mathrm{p}=0,378)$. A presença de folículos linfóides e metaplasia estiveram relacionadas ao Giemsa $\oplus$ ( $p=0,025$ e 0,039). Conclusão: Há prevalência elevada de Helicobacter spp nos doentes com colecistite crônica calculosa sem haver correlação com os achados histológicos estudados.

Descritores: Helicobacter. Reação em Cadeia da Polimerase. Bile. Colecistite.

${ }^{1}$ Research performed at Department of Surgery, Biliary Tract and Pancreas Group, Department of Physiological Sciences and Laboratory of Molecular Medicine, Department of Pathological Sciences and Pathological Anatomy Service, Faculty of Medical Sciences, Santa Casa School of Medicine, São Paulo, Brazil. 


\section{Introduction}

Since the discovery of the Helicobacter pillory ${ }^{1}$, more than 25 species of the genus helicobacter have been isolated from the stomach, intestine and liver of various mammals and birds ${ }^{2}$. Besides ulcerous disease, $H$. pilory is related to the development of gastric adenocarcinoma and MALT lymphoma in the stomach ${ }^{3}$. Recent work demonstrated the presence of $H$. pylori and H. bilis both in the bile and gallbladder of more than $75 \%$ of patients with gallbladder's cancer and more than $50 \%$ of patients with chronic cholecytitis undergoing surgery ${ }^{4}$. It was demonstrated that some species such as entero-hepatic helicobacters could cause chronic active hepatitis in animals and that $H$. hepaticus was related to the appearance of tumors in the liver of mice ${ }^{4,5}$.

The prevalence of infection in the digestive tract by Helicobacter spp varies in the population studied, suggesting epidemiological differences in the distribution of the bacillus in various countries ${ }^{6-8}$. The true prevalence and relationship of different species of helicobacter in the pathogenesis of these diseases is not known.

The stone formation depends on epidemiological, physical, chemical, nutritional, genetic, immunological and infectious factors to occur ${ }^{9,10}$. This last factor has been studied in population where the cholecystholithiasis and intra-hepatic lithiasis are common diseases and the infection by Helicobacter spp very prevalent, as in Chile, Japan, China and Thailand ${ }^{4,9,10}$. The condition most common predisposing for gallbladder's cancer is gallstones ${ }^{11}$. Histological changes, considered pre-neoplastic, were demonstrated in the mucosa of gallbladder, limited to mice infected with Helicobacter spp such as, intestinal metaplasia, hyperplasia, dysplasia in addition to eosinophilic inflammation and hyalinosis 9 . In the histology of tumors of the gallbladder, the inflammatory process is commonly seen ${ }^{12}$. Similar to the development of lowgrade MALT lymphoma in the stomach due to chronic infection of H. pylori $^{3}$, we seek to establish whether there is a relationship with the presence of lymphoid follicles (follicular cholecystitis) and the presence of helicobacter.

For isolation of Helicobacter spp, tissue cultures and seeding of bile have been shown to be negative ${ }^{8,10}$, requiring the direct visualization of the bacillus in the histology using specific dyes such as modified Giemsa ${ }^{13}$, the use of immune-histochemical methods ${ }^{14}$ or by PCR. Finding viable bacteria in the mucosa or in the bile of the gallbladder as Helicobacter spp and establishing a relationship with these changes as mucosal metaplasia and follicular cholecystitis, supported the works described above and open the possibilities to study the changes of biliary epithelial cell, related to the presence of the bacillus. Therefore this study aims to determine the prevalence of Helicobacter spp in the gallbladder bile of patients operated on for chronic cholecystitis and relating their presence to the histological changes, found in the gallbladder mucosa.

\section{Methods}

From february to september 2007,100 cholecystectomies were performed both by open surgery $(22 \%)$ and by laparoscopy (78\%) for symptomatic cholecystholithiasis. We excluded patients from acute cholecystitis, cholangitis, tumors and patients previously treated with antibiotics and proton pump inhibitors. All patients showed chronic cholecystitis in pathological analysis. All patients signed a free and informed consent and this study was approved by the Research Ethics Committee of the Institution where it was held.

During cholecystectomy prior to prophylactic antibiotic therapy, $2.0 \mathrm{ml}$ of bile were collected from the gallbladder through needle puncture. The material was packed in dry sterile tube and stored at $-20^{\circ} \mathrm{C}$. The gallbladder specimen was sent in formalin for pathological analysis. In the laboratory gallbladder was opened on longitudinal way, tree pieces of tissue were removed measuring $1.0 \times 1.0 \mathrm{~cm}$ from the infundibulum, body and background to study the histological changes, and any suspect spots in the mucosa. The histological findings were tabulated to facilitate evaluation. All slides were examined by the pathologist with the researcher and reviewed by a second pathologist to confirm the findings described.

\section{Histological analysis}

Those histological changes that were considered less expected or atypical were those that could be related to the presence of Helicobacter spp: the presence of metaplasia (pyloric and intestinal) dysplasia, anaplasia, lymphoid follicles (follicular cholecystitis), and tumors. Histological changes in the mucosa as atrophy, peeling and hyperplasia; in the muscular layer as hypertrophy and, additional findings such as calcification, infiltration of eosinophils, fibrosis, polyps, etc, were tabulated as well. Furthermore, it was assessed the type of stones found in the gallbladder: cholesterol, pigment and mixed ones.

The identification of the presence of Helicobacter spp was performed by histological analysis of fixed blades in the hematoxylin-eosin and then stained by Wrigth-Giemsa modified solution for identification of Gram-negative spiral bacilli of the genus "helicobacter" (Figures 1 and 2). The next step was the isolation of bacterial DNA in bile by PCR.

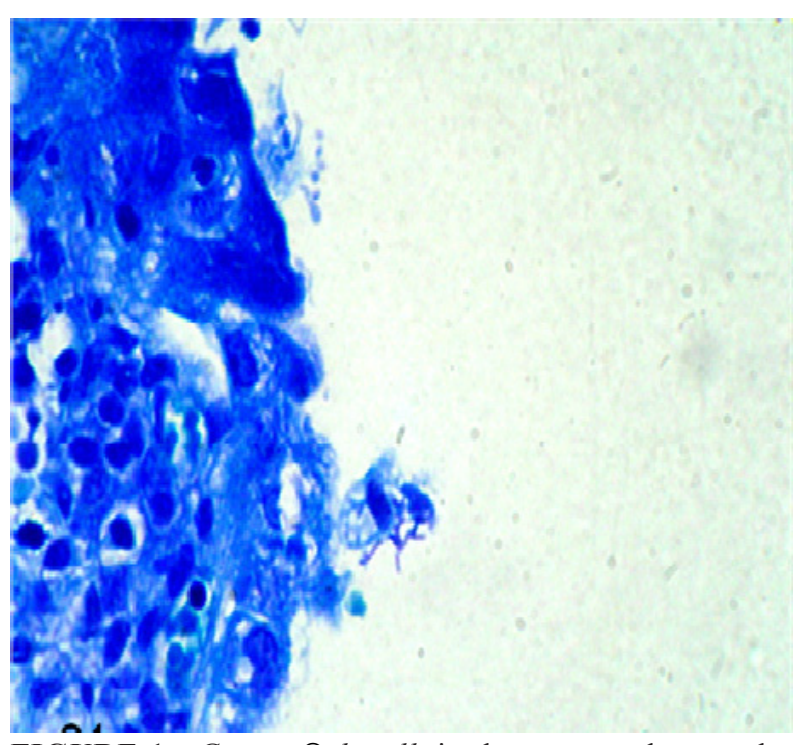

FIGURE 1 - Giems $a \oplus$ bacilli in the mucus, close to the surface 


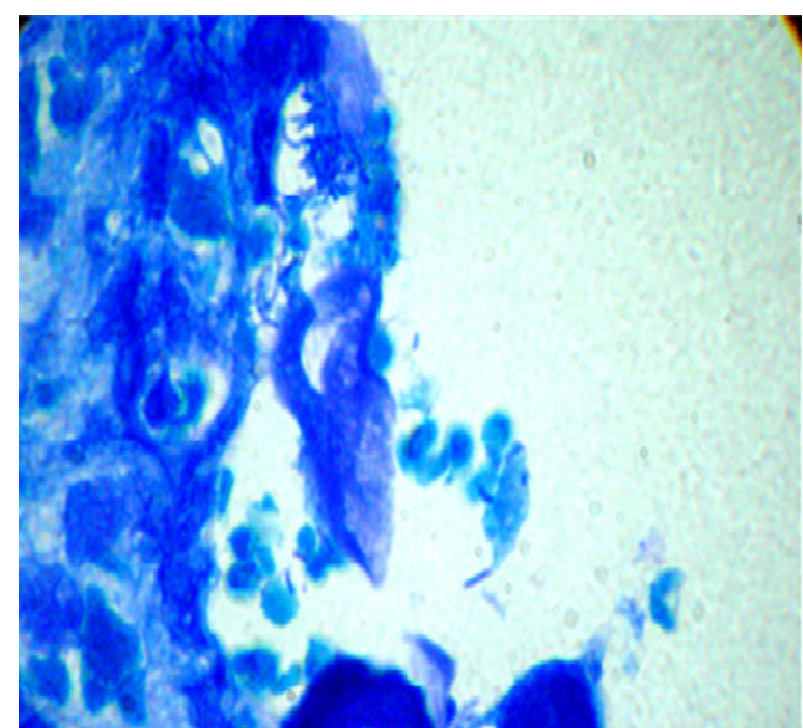

FIGURE 2 - Spiral Giemsa $\oplus$ bacilli inside the mucosa (Modified Giemsa, $>400 x$ )

\section{Protocol for DNA extraction}

For extraction of DNA from bile collected from each sample, the QIAamp DNA Mini Kit (USA,Qiagen Inc Valencia,CA ) was used. The primers for detection of Helicobacter spp was based on paper by SILVA et al. ${ }^{15}$ and validated with BLAST (Basic Alignment Search Tool). The initiators c97f (5' GCTATGACGGGTATCC 3') and c98r (3' GATTTTACCCCTACACCA 5') amplify a segment of 400bp mithochondrial rRNA in the $16 \mathrm{~S}$ gene, common to all species of helicobacter. The PCR reaction for Helicobacter spp was validated with positive control DNA of H. pylori (Figure 3).

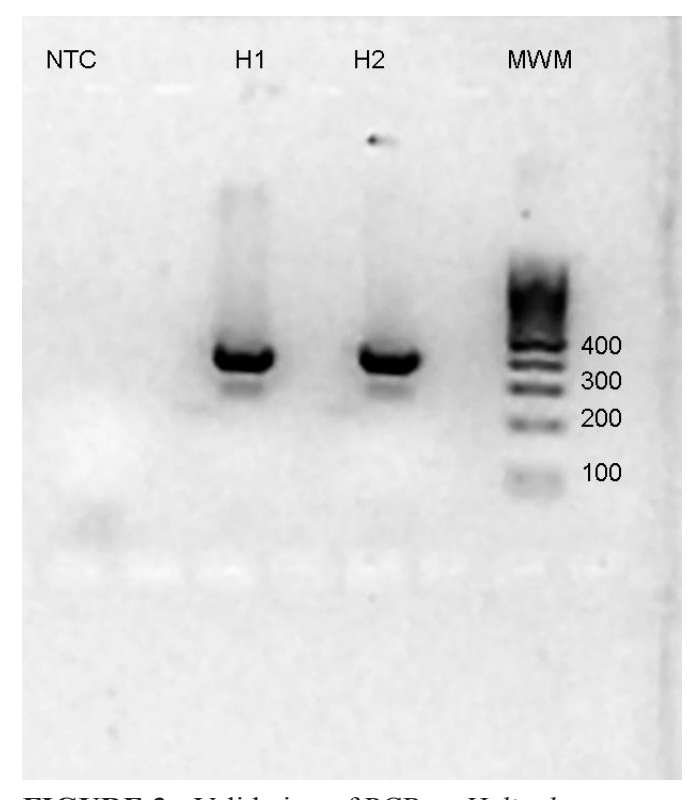

FIGURE 3 - Validation of PCR to Helicobacter spp

The PCR reactions were performed using $100 \mu$ l solution to which were added $1.0 \mu \mathrm{l}$ of DNA from each sample, containing
$12.5 \mu 1$ of Platinum Supermix (1.0\% of polymerase buffer, taq polymerase), $0.6 \mu \mathrm{l}$ of sense primer c $97 \mathrm{f}, 0.6 \mu \mathrm{l}$ of anti-sense primer c98r and $10 \mu \mathrm{l}$ of $\mathrm{ddH}_{2} \mathrm{O}$. The reactions occurred in the Applied Biosytems thermocycler (ABI 9700) under the following conditions: $94^{\circ} \mathrm{C}$ for 5 minutes for activation of Taq polymerase, followed by 35 cycles at $94^{\circ} \mathrm{C}$ for 30 seconds, $55^{\circ} \mathrm{C}$ for 2 minutes, $72^{\circ} \mathrm{C}$ for 3 minutes and final extension of 5 minutes at $72^{\circ} \mathrm{C}$. The amplified product runs in $1.0 \%$ agarose under $90 \mathrm{~V}$ (Figure 4 ).

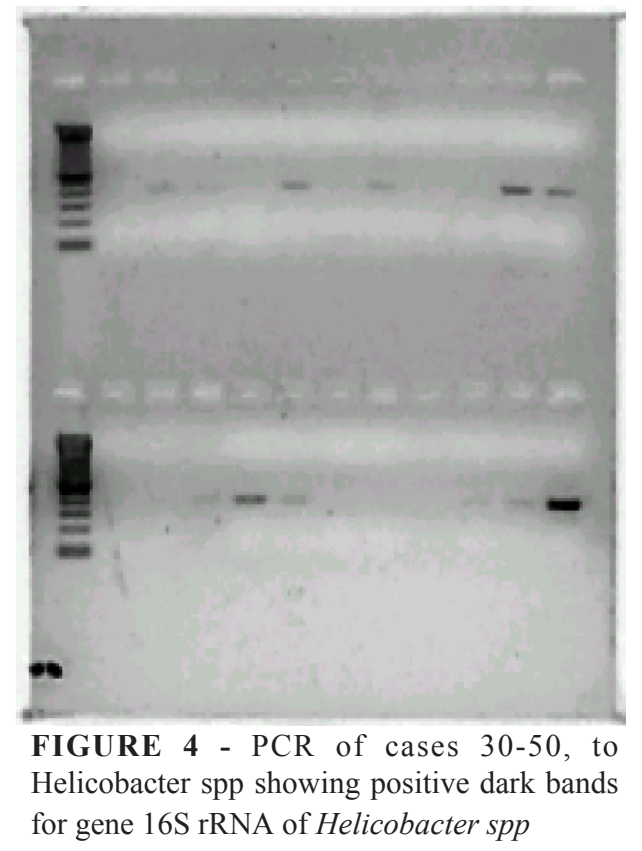

The positive control for the presence of human DNA in samples of bile was performed using Platinum Supermix with GAP60-sense primer (5'TCTCCAGAACATCATCCCTGCCTC3') and GAP60-antisense (3'TGGGCCATGAGGTCCACCCTG5') within the same standards described above plus a negative control NTC.

The DNA samples that were negative in PCR for Helicobacter spp and GAPDH, showing no genetic material isolated in the bile collected, were excluded from the study. The cases with positive genetic material (GAPDH) and negative for both Giemsa and PCR for the presence of helicobacter were used as control group. Once identified samples with presence of Helicobacter spp in the PCR, they were correlated with histological findings and with Giemsa and compared with the control group and the results subjected to statistical analysis.

\section{Statistics}

The histological findings were considered as independent variables and correlated with Wrigth-Giemsa and the results were analyzed by Pearson's Chi-square test ( $p<0.05, \mathrm{CI}=95 \%)$. The frequency of histological findings described was compared with the PCR using Fisher's exact test when there were more than two independent variables and Pearson's Chi-square for the rest. The results of PCR were compared to the Giemsa to assess the sensitive detection of bacillus by histological staining. Statistical Package for Social Science (SPSS) version 15.0 software was used for statistical analysis. 


\section{Results}

Of the 100 gallbladders, in 31 cases the PCR was negative for the presence of Helicobacter spp and human DNA. One patient had histological diagnosis of acute cholecystitis and was excluded. Therefore, we conclude the study with 68 patients. Of these, $18(62.5 \%)$ were men and $50(73.5 \%)$ women with a mean age of 48.3 years ( 23 to 77 years). The average length of history of pain was 32.9 months ranging from 30 days to 420 months. Two patients $(2.9 \%)$ had a history of acute billiary pancreatitis. Additional findings during the surgery were: hydropic gallbladder in $6(8.8 \%)$, non alcoholic hepatic steatosis in $3(4.4 \%)$, scleroatrophic gallbladder in $7(10.3 \%)$, choledocholithiasis in $2(2.9 \%)$, cholesterolosis in $18(26.5 \%)$. There was no presence of malignant tumors in the gallbladders studied. The histological results are listed in Table 1. Among them, 37 (54.4\%) had less expected findings other than chronic cholecystitis. The types of gallstones were: cholesterol in 25 $(36.8 \%)$, mixed in $22(32.3 \%)$ and pigment in $21(30.9 \%)$.

TABLE 1 - Histological findings

\begin{tabular}{lc}
\hline Histology & $\boldsymbol{n}(\boldsymbol{( \% )}$ \\
\hline Atrophy of the mucosa & $68(100.0)$ \\
Muscle layer without hypertrophy & $5(7.4)$ \\
Mild hypertrophy & $11(16.2)$ \\
Moderate hypertrophy & $43(63.2)$ \\
Severe hypertrophy & $9(13.2)$ \\
Metaplasia & $20(29.4)$ \\
Lymphoid Follicles & $6(8.8)$ \\
Follicles and metaplasia & $10(14.7)$ \\
Dysplasia & $1(1.5)$ \\
Fibrosis & $36(52.9)$ \\
Adenomyosis & $1(1.5)$ \\
Haemorrhage & $12(17.6)$ \\
\hline Total & $68(100.0)$ \\
\hline
\end{tabular}

Of the 68 cases, $42(61.8 \%)$ were positive for the presence of DNA of Helicobacter spp in the PCR $(\mathrm{PCR} \oplus)$ and, 19 $(27.9 \%)$ were positive for the presence of bacilli to optical microscope $($ Giemsa $\oplus)$. Eighteen patients $(26.5 \%)$ were Giemsa $\Theta$ and $\mathrm{PCR} \Theta$ at the same time.There are then two groups within the sample: Group I - cases PCR positive for Helicobacter spp (more sensitive method for detection of helicobacter), Group II (control group) - Giemsa $\Theta$ and PCR $\Theta$ and GAPDH $\oplus$ ). The two groups were similar and can be compared (Table 2).

TABLE 2 - Characterization of Groups I and II

\begin{tabular}{lccc}
\hline & $\begin{array}{c}\text { Group I } \\
\mathbf{n = 4 2 ~ ( \% )}\end{array}$ & $\begin{array}{c}\text { Group II } \\
\mathbf{n = 1 8 ~ ( \% )}\end{array}$ & p \\
\hline Male & $8(19.0)$ & $6(33.3)$ & 0.386 \\
Mean age (SD) & $47,8(14.9)$ & $47,0(11.8)$ & 0.828 \\
Time history (m) (SD) & $38,1(78.8)$ & $26,1(31.9)$ & 0.481 \\
Prior biliary pancreatitis & $1(2.4)$ & $0(0.0)$ & 0.665 \\
Liver disease & $2(4.8)$ & $1(5.6)$ & 0.607 \\
Choledocholithiasis & $1(2.4)$ & $1(5.6)$ & 0.88 \\
Hydropic gallbladder & $2(4.8)$ & $2(11.1)$ & 0.751 \\
Scleroatrophic & $4(9.5)$ & $2(11.1)$ & 0.77 \\
Cholesterolosis & $14(33.3)$ & $4(22.2)$ & 0.581 \\
\hline
\end{tabular}

$\mathrm{m}=$ month

$\mathrm{SD}=$ standard deviation

\section{Atypical histological changes X Giemsa}

Of the 19 patients with Giemsa $\oplus$ under optical microscopy 12 (63.2\%), had atypical histological findings. When compared Giemsa to histological changes, the gallbladders with metaplasia and follicles showed statistically significant differences
(Table 3). When correlated specifically the presence of lymphoid follicles in the mucosa of the gallbladder (follicular cholecystitis) with the presence of bacilli, there was significant statistical correlation $(p=0.025)$. There was no correlation between follicular cholecystitis with the Helicobacter spp in the PCR $(p=0.511)$. 
TABLE 3 - Analysis of histological changes related to Giemsa

\begin{tabular}{cccc}
\hline Histology & $\begin{array}{c}\text { Giemsa } \boldsymbol{\Theta} \\
\boldsymbol{n}(\%)\end{array}$ & $\begin{array}{c}\text { Giemsa } \oplus \\
\boldsymbol{n}(\%)\end{array}$ & $\begin{array}{c}\boldsymbol{p} \\
\boldsymbol{X}^{\mathbf{2}}\end{array}$ \\
\hline Without changes & $25(51.0)$ & $7(36.8)$ & 0.434 \\
Metaplasia & $16(32.6)$ & $4(21.1)$ & 0.524 \\
Lymphoid follicles & $4(8.2)$ & $2(10.5)$ & 0.860 \\
Follicles+metaplasia & $4(8.2)$ & $6(31.6)$ & $0.039^{*}$ \\
\hline Total & $49(72.1 \%)$ & $19(27.9 \%)$ & \\
\hline
\end{tabular}

\section{Atypical histological changes X PCR}

Of the 42 patients with $\mathrm{PCR} \oplus$ fort the presence of Helicobacter spp 24 (57.1\%) had atypical histological changes. When compared to patients with negative PCR, there was no statistically significant difference (Table 4). Of the total sample of 68 patients, only $1(1.5 \%)$ had dysplasia in the histology, and PCR and Giemsa were both negative. Only one of 68 cases showed adenomyosis and was Giemsa $\oplus$ and PCR $\Theta$.

TABLE 4 - Analysis of histological changes related to PCR

\begin{tabular}{ccccc}
\hline & $\boldsymbol{P C R} \boldsymbol{\Theta}$ & $\boldsymbol{P C R} \oplus$ & Total & $\boldsymbol{p}$ \\
& $\boldsymbol{n}(\%)$ & $\boldsymbol{n}(\%)$ & $\boldsymbol{n}(\%)$ & $\boldsymbol{X}^{\mathbf{2}}$ \\
\hline Without changes & $14(53.8)$ & $18(42.9)$ & $32(47.1)$ & 0.798 \\
Metaplasia & $7(26.9)$ & $13(31.0)$ & $20(29.4)$ & 0.89 \\
Lymphoid follicles & $1(3.9)$ & $5(11.9)$ & $6(8.8)$ & 0.867 \\
Follicles+metaplasia & $4(15.4)$ & $6(14.2)$ & $10(14,7)$ & 0.683 \\
\hline Total & $26(100.0)$ & $42(100.0)$ & $68(100.0)$ & \\
\hline
\end{tabular}

\section{Comparison between Giemsa and PCR}

Of the 42 patients with $\mathrm{PCR} \oplus$ for Helicobacter spp, 11 $(26.2 \%)$ were positive for Giemsa. Of the 26 cases PCR $\Theta 8$ (30,8\%) were Giemsa $\oplus$. When compared the histological changes of the gallbladder and the presence of helicobacter by the methods used there was no statistical correlation between Giemsa and PCR (Table 5).

There was no significant statistical correlation between the additional histological findings such as fibrosis, bleeding and types of gallstones as well as the various grades of hypertrophy when comparing Giemsa versus PCR.

TABLE 5 - Comparison between modified Wright - Giemsa and PCR

\begin{tabular}{cccc}
\hline Histology & $\mathbf{G} \oplus / \boldsymbol{P C R} \boldsymbol{\Theta}$ & $\mathbf{G} \boldsymbol{\Theta} / \boldsymbol{P C R} \oplus$ & $\boldsymbol{p}$ \\
& $\boldsymbol{n}(\%)$ & $\boldsymbol{n}(\%)$ & $\boldsymbol{X}^{\mathbf{2}}$ \\
\hline Without changes & $4(50.0)$ & $15(48.3)$ & 0.756 \\
Metaplasia & $1(12.5)$ & $10(32.3)$ & 0.504 \\
Lymphoid follicles & $0(0.0)$ & $3(9.7)$ & 0.862 \\
Follicles+metaplasia & $3(37.5)$ & $3(9.7)$ & 0.164 \\
\hline Total & $8(100.0)$ & $31(100.0)$ & \\
\hline
\end{tabular}

\section{Histological findings X Group I X Group II (Control} Group)

When comparing the histological findings of the gallbladder form the Group I $(\mathrm{PCR} \oplus)$ to the Group II, there was no statistical correlation between them. All 68 gallbladders showed atrophy and exfoliation of mucosa as part of the typical aspect of the chronic cholecystitis. Grade of muscle hypertrophy, cholesterolosis, types of gallstones and intra-operative findings such as choledocholithiasis, scleroatrophic and hydropic gallbladder showed no significant difference between the two groups of patients. 
There was no difference in the gender for PCR or even for the Giemsa when both methods were compared. When analyzing the mean age for patients with the presence of follicles, which was 57 years, it was significantly higher than that observed in patients without lymphoid follicles, which was 47.4 years $(p=0.035)$.

\section{Discussion}

From reports in literature $e^{9,15,16}$ referring about the isolation of helicobacter species in bile from the liver and particularly of the gallbladder and its implications in the pathogenesis of diseases, we became interested to assess the prevalence of Helicobacter spp in patients operated on for chronic cholecystitis .

Based on evidence of pathogenic mechanisms in the inflammatory process caused by helicobacter in the gallbladder mucosa $a^{10,17}$ and controversies about the bacillus being responsible for changes in the gallbladder's epithelium ${ }^{18}$, we tried to correlate the presence of Helicobacter spp and atypical histological changes in chronic gallstone cholecystitis.

Of the 100 cases originally studied, only $68 \%$ of patients in the sample showed evidence of DNA after extraction with QIAamp DNA Mini Kit. It is a rate of extraction of genetic material considered to be low, a finding that this made us question the efficiency of the method used. But several factors such viscosity and $\mathrm{ph}$ of the bile may have hindered the process of dilution and membrane filtration ${ }^{15}$. We found that eventually the amount of bile collected ( 2 to $3 \mathrm{ml}$ ) was not enough. We should have collected the entire vesicular contents and increased the volume of dilution to achieve better results.

The prevalence of Helicobacter spp in our series was $61.8 \%$ and the optical microscope to view Giemsa positive bacilli was $27.9 \%$. It is a similar prevalence when compared to data from the Chilean and Asian population, higher than previous data from our environment $t^{4,9,10,15}$. Perhaps the findings may be related to the fact that the population studied includes only patients with chronic inflammatory processes, which further selected the sample.

The comparison between the sensitivity of the method of microscopy and that of molecular detection should be done with care. The option of utilizing modified Wrigth-Giemsa staining method was due to it being practical fast and widely used in the analysis of gastric mucosa to searching Gram-negative spiral bacilli. The fact that we find cocoidal and spiral forms in microscopy suggests that the bacilli Giemsa $\oplus$ may have been fixed in their viable form. We did not perform immunological tests which prevented us identify the kind of bacilli found. Only $26.2 \%$ of the Giemsa $\oplus$ patients were PCR $\oplus$ suggesting that they were probably of the same genus.

Several factors may be related to changes in the columnar epithelium in the presence of inflammation with or without cholelithiasis. Other bacteria can colonize the bile from the gallbladder in the presence of stones and cause inflammatory changes such as E. coli and Salmonella typhi ${ }^{19}$. The types of gallstones of cholesterol, mixed or pigment may be related to inflammatory process, mainly by the joint action of bile salts, a chronic irritant of the mucosa?

The most common type of metaplasia is pyloric, which seems not to be related to the development of tumors. Several studies related to intestinal metaplasia as a risk for gallbladder tumor $^{18}$. As with the carcinogenetic process of the stomach and colon, the same process is tried to be applied to gallbladder cancer, trying to explain its formation from the metaplasia to carcinoma through the dysplasia ${ }^{18}$. In the histology of tumors of gallbladder the inflammatory process is frequently found ${ }^{12}$. In the study of pathogenic mechanisms responsible for inflammation, lipopolysaccharide of the membrane expressed in certain species of entero-hepatic helicobacter, increased the inflammatory activity with consequent production of cytokines and aggression of the epithelium ${ }^{17}$.

When analyzing the presence of bacilli in Giemsa $\oplus$ by microscopy with the presence of atypical histological changes such as metaplasia or the presence of lymphoid follicles, we found statistical correlation in comparison to patients without bacteria. Although $12(63.2 \%)$ of 19 patients Giemsa $\oplus$ have histological changes the number of patients was small. The presence of follicular cholecystitis is a histological change that may be related to the presence of Helicobacter spp as such as the development of MALT lymphoma in the stomach. Even if there was no correlation between microscopic and molecular methods, and that not all the bacilli Giemsa $\oplus$ were demonstrated as helicobacter, this finding suggests that the presence of bacteria may be responsible for stimulation of lymphocytes and the generation of clones of cells to lymphoid follicles ${ }^{3,10,17}$. An average age of 57 years was found for the appearance of lymphoid follicles in relation to patients who showed no such condition, suggests that the time of exposure to the bacillus have a crucial role in the development of follicular cholecystitis. Although, for atypical histological changes, no statistical significance between patients with $\mathrm{PCR} \oplus$ and $\mathrm{PCR} \Theta$ was shown, $24(57.1 \%)$ patients had metaplasia with or without lymphoid follicles. It was a large number of cases with changes considered atypical.

Another factor that can be seen in the lack of correlation between the findings of Giemsa and PCR is that the search of Helicobacter spp by molecular way was done in the bile but not in the tissue. The bacilli were seen through the Giemsa in the mucus and in the mucosa of gallbladder. If have we searched in the tissue, we could also have found increased prevalence of helicobacter. Several research studies have found Helicobacter spp in both the bile, as in the mucosa and even in the gallstones, with different incidences depending on the population studied and method used $^{4,7,9}$.

Additional findings such as type of stones, hemorrhage, fibrosis and muscular hypertrophy are considered benign histological changes and, were not associated with helicobacter infection.

In our study, we have identified that the group of patients with chronic gallstone cholecystitis the prevalence of Helicobacter spp was high. However in the methodology used, there was no relationship between presence of the bacillus and the histological changes described as being atypical. Following the postulates described by $\mathrm{Koch}^{20}$, we found the bacteria colonizing the body suffering the disease. We do not know which of helicobacter species was identified and the next step of the study, through genetic sequencing, will be to recognize the type of bacteria that colonizes our population of patients ${ }^{17}$. The identification of the species of helicobacter has epidemiological significance. Once linked in the pathogenesis of gallbladder diseases, such knowledge will help in preventing infection and in the eradication of animal vectors. 
The probable pathogenic mechanisms of bacilli causing cholecystolithiasis and even tumors of the gallbladder are being thoroughly studied especially in places like Chile, where the disease is very common. There is a long way to be travelled in order to confirm whether the Helicobacter spp, due to its high prevalence in patients with chronic cholecystitis, is a saprophyte organism or is actually causing the gallbladder diseases.

\section{Conclusion}

There is a high prevalence of Helicobacter spp in the patients with chronic gallstone cholecystitis without, however, having correlation with changes on the histological pattern of the gallbladder.

\section{References}

1. Marshal BJ, Warren JR. Unidentified curved bacilli in the stomach of patients with gastritis and peptic ulceration. Lancet. 1984;1(8390):1311-5. 2. Andersen LP. New Helicobacter species in humans. Dig Dis. 2001;19(2):112-5.

3. Montalban C, Manzanal A, Boixeda D, Redondo C, Alvarez I, Calleja JL, Bellas C. Helicobacter pylori eradication for the treatment of low-grade gastric MALT lymphoma: follow-up together with sequential molecular studies. Ann Oncol. 1997;8 Suppl 2:37-9.

4. Matsukura N, Yokomuro S, Yamada S, Tajiri T, Sundo T, Hadama T, Kamiya S, Naito Z, Fox JG. Association between Helicobacter bilis in bile and biliary tract malignancies: H. bilis in bile from Japanese and Thai patients with benign and malignant diseases in the biliary tract. Jpn J Cancer Res. 2002;93(7):842-7.

5. Ward JM, Fox JG, Anver MR, Haines DC, George CV, Collins MJ Jr, Gorelick PL, Nagashima K, Gonda MA, Gilden RV. Chronic active hepatitis and associated liver tumors in mice caused by a persistent bacterial infection with a novel Helicobacter species. J Natl Cancer Inst. 1994;86(16):1222-7. 6. Kikuchi S, Dore MP. Epidemiology of Helicobacter pylori Infection. Helicobacter. 2005;10 Suppl 1:1-4.

7. Méndez-Sánchez N, Pichardo R, González J, Sánchez H, Moreno M, Barquera F, Estevez HO, Uribe M. Lack of association between Helicobacter sp colonization and gallstone disease. J Clin Gastroenterol. 2001;32(2):138-41.

8. Bohr UR, Kuester D, Meyer F, Wex T, Stillert M, Csepregi A, Lippert $\mathrm{H}$, Roessner A, Malfertheiner P. Low prevalence of Helicobacteraceae in gall-stone disease and gall-bladder carcinoma in the German population. Clin Microbiol Infect. 2007;13(5):525-31.

9. Maurer KJ, Ihrig MM, Rogers AB, Ng V, Bouchard G, Leonard MR, Carey MC, Fox JG. Identification of cholelithogenic enterohepatic helicobacter species and their role in murine cholesterol gallstone formation. Gastroenterology. 2005;128(4):1023-33.

10. Maurer KJ, Rao VP, Ge Z, Rogers AB, Oura TJ, Carey MC, Fox JG. T-cell function is critical for murine cholesterol gallstone formation. Gastroenterology. 2007;133(4):1304-15.

11. Strom BL, Soloway RD, Rios-Dalenz JL, Rodriguez-Martinez HA, West SL, Kinman JL, Polansky M, Berlin JA. Risk factors for gallbladder cancer. An international collaborative case-control study. Cancer. 1995;76(10):1747-56

12. Fukuda K, Kuroki T, Tajima Y, Tsuneoka N, Kitajima T, Matsuzaki S, Furui J, Kanematsu T. Comparative analysis of Helicobacter DNAs and biliary pathology in patients with and without hepatobiliary cancer. Carcinogenesis. 2002;23(11):1927-31.

13. Goodwin CS, Armstrong JA. Microbiological aspects of Helicobacter pylori (Campylobacter pylori). Eur J Clin Microbiol Infect Dis. 1990;9(1):1-13. 14. Apostolov E, Al-Soud WA, Nilsson I, Kornilovska I, Usenko V, Lyzogubov V, Gaydar Y, Wadström T, Ljungh A. Helicobacter pylori and other Helicobacter species in gallbladder and liver of patients with chronic cholecystitis detected by immunological and molecular methods. Scand J Gastroenterol. 2005;40(1):96-102.

15. Silva CP, Pereira-Lima JC, Oliveira AG, Guerra JB, Marques DL, Sarmanho L, Cabral MM, Queiroz DM. Association of the presence of Helicobacter in gallbladder tissue with cholelithiasis and cholecystitis. J Clin Microbiol. 2003;41(12):5615-8.

16. Fox JG, Dewhirst FE, Shen Z, Feng Y, Taylor NS, Paster BJ, Ericson RL, Lau CN, Correa P, Araya JC, Roa I. Hepatic Helicobacter species identified in bile and gallbladder tissue from Chileans with chronic cholecystitis. Gastroenterology. 1998;114(4):755-63.

17. Mandell L, Moran AP, Cocchiarella A, Houghton J, Taylor N, Fox JG, Wang TC, Kurt-Jones EA. Intact gram-negative Helicobacter pylori, Helicobacter felis, and Helicobacter hepaticus bacteria activate innate immunity via toll-like receptor 2 but not toll-like receptor 4. Infect Immun. 2004;72(11):6446-54.

18. Misra V, Misra SP, Dwivedi M, Shouche Y, Dharne M, Singh PA. Helicobacter pylori in areas of gastric metaplasia in the gallbladder and isolation of H. pylori DNA from gallstones. Pathology. 2007;39(4):419-24. 19. Nath G, Singh H, Shukla VK. Chronic typhoid carriage and carcinoma of the gallbladder. Eur J Cancer Prev. 1997;6(6):557-9.

20. Falkow S. Molecular Koch's postulates applied to microbial pathogenicity. Rev Infect Dis. 1988;10 Suppl 2:S274-6.

\section{Correspondence:}

André de Moricz

Rua Sincorá, 127

04650-000 São Paulo - SP Brazil

Phone: (55 11)5681-7639 / 2176-7271

amoricz@uol.com.br cir.pancreas@santacasasp.org.br

Conflict of interest: none Financial source: $\mathrm{CNPq}$

\section{How to cite this article}

Moricz A, Melo M, Castro AM, Campos T, Silva RA, Pacheco Jr AM. Prevalence of Helicobacter spp in chronic cholecystitis and correlation with changes on the histological pattern of the gallbladder. Acta Cir Bras. [serial on the Internet] 2010 May-Jun;25(3). Available from URL: http://www.scielo.br/acb 